\title{
HUBUNGAN ANTARA PENGGUNAAN FASILITAS BELAJAR DENGAN MOTIVASI BELAJAR KIMIA PADA ERA WABAH COVID-19
}

\author{
Noni Pratiwi ${ }^{1 *}$, Wildan ${ }^{2}$, I Nyoman Loka ${ }^{3}$, Muntari ${ }^{4}$ \\ 1234 Program Studi Pendidikan Kimia, Universitas Mataram. Jalan Majapahit No. 62 \\ Mataram, NTB 83112, Indonesia. \\ * Coressponding Author. E-mail: nonipratiwi28@gmail.com
}

Received: 13 Juli 2021

Accepted: 30 November 2021 Published: 30 November 2021

doi: 10.29303/cep.v4i3.2801

\begin{abstract}
Abstrak
Penelitian deskriftif kuantitatif ini bertujuan untuk mengetahui kekuatan hubungan antara penggunaan fasilitas belajar dengan motivasi belajar kimia pada era wabah Covid-19 pada siswa kelas XI IPA SMAN 1 Pringgarata tahun 2021 dengan menggunakan metode penelitian survei. Adapun rancangan dalam penelitian ini ialah penelitian korelasional. Populasi dalam penelitian berjumlah 90 siswa. Jumlah sampel sebanyak 60 orang siswa yang diambil menggunakan teknik cluster sampling. Pengumpulan data menggunakan angket yang telah divalidasi. Hasil penelitian menunjukkan bahwa terdapat hubungan yang positif dan signifikan antara penggunaan fasilitas belajar dengan motivasi belajar siswa yang ditunjukkan oleh persamaan regresi $\hat{Y}=15,162+0,671 \mathrm{X}$ dengan koefisien korelasi $\left(\mathrm{r}_{\mathrm{xy}}\right)$ $=0,529$. Kontribusi penggunaan fasilitas belajar 28,04\% terhadap motivasi belajar.
\end{abstract}

Kata Kunci: fasilitas belajar, motivasi belajar, era wabah covid 19

\section{The Correlation Between The Use of Learning Facilities With The Motivation To Learn Chemistry in The Age of The Outbreak Covid-19}

\begin{abstract}
This quantitative descriptive study aims to determine the strength of the relationship between the use of learning facilities and motivation to learn chemistry in the age of the Covid-19 in XI IPA class students of senior high school 1 Pringgarata in the year of 2021 using survey research methods. The design in this research is correlational research. The population in the study amounted to 90 students. The samples amounted 60 students were taken using cluster sampling technique. Data collecting was use validated questionnaire. The findings showed there was a positif and significant relationship between the use of learning facilities and students' learning motivation as indicated by the regression equation $\hat{Y}=$ $15,162+0,671 X$ with a correlation coefficient $(r x y)=0,529$. The Contribution of the use of learning facilities $28.04 \%$ to learning motivation.
\end{abstract}

Keywords: learning facilities, learning motivation

\section{PENDAHULUAN}

Pandemi Covid-19 merupakan musibah yang memilukan seluruh penduduk bumi. Seluruh segmen kehidupan manusia di bumi terganggu, tanpa kecuali pendidikan.Banyak negara memutuskan menutup sekolah, perguruan tinggi maupun universitas, termasuk Indonesia (Aji, 2020). Dalam rangka mencegah meluasnya penularan Covid-19 pada masyarakat luas pada umumya dan pada warga sekolah khususnya, maka Kemendikbud menerbitkan beberapa surat edaran terkait pencegahan dan penanganan Covid-19. Salah satu surat edaran dari Kemendikbud diantaranya Surat Edaran Nomor 4 Tahun 2020 tentang Pelaksanaan Kebijakan Pendidikan saat Masa Darurat Penyebaran Coronavirus Disease (Covid-19), dalam hal ini memuat arahan tentang proses belajar mengajar yang dapat dilaksanakan dari rumah sehingga berbagai wilayah menetapkan kebijakan belajar dari rumah 


\section{Chemistry Education Practice, 4 (3), 2021 - 282}

Pratiwi, Wildan, Loka, Muntari

yang menyasar seluruh jenjang pendidikan mulai dari jenjang prasekolah hingga pendidikan tinggi, baik negeri maupun swasta (Arifa, 2020).

Tidak dapat dipungkiri bahwa pandemi Covid-19 telah merubah tatanan hidup sebagian besar penduduk dunia, termasuk dalam dunia pendidikan. Penyampaian pendidikan, dalam kegiatan formal maupun informal dialihkan pada metode online atau dalam jaringan. Mau tidak mau, baik informan (guru, dosen, pengajar, pendidik) maupun sasaran informasi harus melek teknologi. Jika tidak, maka harus bersiap mengalami ketertinggalan (Rachmawati, 2020).

Salah satu bentuk pembelajaran alternatif yang dapat dilaksasnakan selama masa darurat Covid-19 adalah pembelajaran secara daring. Pembelajaran daring merupakan salah satu jenis pembelajaran jarak jauh (PJJ) (Kusuma, 2020). Sistem pembelajaran daring adalah sistem pembelajaran yang dilakukan secara online dengan jaringan internet. Proses pembelajaran daring dapat dilakukan dengan berbagai aplikasi yang dapat mendukung, seperti whatsapp, telegram, zoom meeting, google meet, google classroom, quiepper school, ruang guru dan berbagai aplikasi lainnya (Zahro, 2020).

Implementasi pembelajaran daring, membutuhkan dukungan perangkatyang dapat dijadikan sebagai fasilitas dalam belajar daring seperti telepon, laptop, dan tablet yang nantinya dapat mereka gunakan untuk mengakses informasi dimana sajadan kapan saja.Penggunaan teknologi mobile memiliki kontribusi besar di dunia pendidikan, termasuk di dalamnya adalah pencapaian tujuan pembelajaran jarak jauh (Firman, 2020).

Permasalahan utama pendidikan saat ini adalah meningkatkan kualitas pada semua jenjang dan jenis pendidikan. Kualitas pendidikan saat ini tengah mengalami tantangan sebagai dampak mewabahnya virus Covid-19 (Cahyani, 2020).

Kualitas pendidikan juga dipengaruhi banyak faktor, salah satunya adalah motivasi pelajar dalam belajar. Motivasi belajar tidak hanya tercermin dari prestasi yang dimiliki, tapi ia harus tampak pada perilaku yang dapat membentuk prestasi itu sendiri, yaitu: choice of tasks (pemilihan tugas), effort (usaha yang keras), dan persistence (Djuarsa, 2017).

Didalam proses pembelajaran motivasi memegang peranan yang sangat penting. Tanpa motivasi, seseorag tidak antusias dalam melakukan kegiatan belajar. Motivasi berkaitan dengan dorongan yang membuat individu melakukan berbagai aktivitas tertentu. Menurut Adiputra (2017), motivasi dapat juga didefinisikan sebagai kekuatan yang mendorong arah dan tindakan menuju suatu tujuan. Tindakan individu dimulai dari suatu dorongan motivasi diri. Menurut Cahyani (2020), motivasi belajar adalah dorongan yang terletak di dalam diri peserta didik yang dapat memunculkan niat untuk melakukan kegiatan belajar, sehingga tujuan yang dikehendaki oleh subjek belajar itu dapat tercapai (Ariani dkk, 2013).

Selain motivasi dalam belajar, fasilitas belajar juga menjadi faktor yang dapat mempengaruhi kualitas pendidikan. Fasilitas belajar sangat dibutuhkan oleh siswa dalam melakukan proses pembelajaranterutama dengan adanya wabah Covid-19 ini. Menurut Roskiana (2020), apabila fasilitas yang dimiliki lengkap dan dapat digunakan dengan baik maka dapat mendukung siswa dalam belajar yang nantinya dapat meningkatkan motivasi belajar siswa.

Jika fasilitas belajar tidak memadai dan tidak digunakan dengan baik maka proses pembelajaran akan terhambat. Sehingga fasilitas belajar bila digunakan dengan baik dapat memperlancar dan memudahkan siswa dalam kegiatan pembelajaran. Hal inilah yang menyebabkan pemanfaatan fasilitas dengan baik sangat penting dalam kegiatan pembelajaran.

Semakin baik dan lengkap fasilitas yang diberikan apabila digunakan dengan baik maka akan menambah motivasi belajar siswa dalam proses pembelajaran sebaliknya bila fasilitas hanya apa adanya dan salah dalam menggunakan fasilitas yang ada tentunya akan mempengaruhi motivasi belajar siawa.

Hal ini sejalan dengan penelitian yang dilakukan oleh Susila (2014), 
menjelaskan bahwa terdapat hubungan yang positif dan signifikan antara kelengkapan fasilitas belajar dengan motivasi belajar siswa kelas $\mathrm{X}$ jurusan teknik gambar bangunan SMKN 1 Rembang.

Berdasarkan pengamatan yang dilakukan saat melaksanakan PLP di SMAN 1 Pringgarata didapatkan beberapa permasalahan yang peneliti amati bahwa masih rendahnya motivasi belajar siswa yang di tandai dengan beberapa permasalahan yang ditemui seperti: tugas yang diberikan dikerjakan satu untuk semua dan ada juga beberapa siswa yang tidak mengerjakan tugas yang diberikan. Ketika pembelajaran berlangsung masih banyak siswa yang tidak peduli dengan apa yang sedang dipelajari dan jadwal mata pelajaran apa yang akan mereka pelajari. Ketika pembelajaran kimia secara daring dilakukan terdapat beberapa siswa yang tidak mengikuti pembelajaran kimia melalui daring tersebut, mereka hanya absen saja dan ketika proses pembelajaran hanya beberapa siswa yang mengikuti pembelajaran daring tersebut bahkan ketika guru memberikan tugas catatan yang harus dicatat melalui WhatApp maupun Google Class Room, ternyata masih banyak siswa yang belum mencatat terutama pada materi hitungan yang menurut mereka pelajaran kimia untuk hitung-hitungan itu sulit untuk mereka pahami.

Dari hasil pengamatan tersebut, peneliti berasumsi bahwa faktor yang mempengaruhi motivasi belajar siswa ialah penggunan fasilitas belajar daring. Siswa yang mempunyai fasilitas belajar daring yang lengkap seperti handphone, kuota ataupun sinyal lebih menggunakan fasilitas yang mereka miliki untuk main game, nonton drakor, tiktok, instagram, dan youtube dan tidak digunakan untuk mencari materi, untuk menerima materi, untuk berdiskusi dengan teman mengenai pelajaran yang diberikan, dan untuk menonton video pembelajaran yang diberikan. Sehingga ketika pembelajaran daring terdapat siswa yang tidak mengikuti pembelajaran kimia tersebuat.

Berdasarkan uraian di atas maka permasalahan yang diajukan dalam penelitian ini ialah "hubungan antara penggunaan fasilitas belajar dengan motivasibelajar kimia pada era wabah Covid-19 pada siswa kelas XI IPA SMAN 1 Pringgarata tahun 2021”.

\section{METODE PENELITIAN}

Penelitian ini merupakan penelitian deskriptif kuantitatif dengan jenis penelitian adalah penelitian yang digunakan adalah penelitian survei.Populasi yang digunakan dalam penelitian ini adalah adalah seluruh siswa kelas XI IPA SMAN 1 Pringgarata tahun ajaran 2020/2021 sebanyak 90 orang siswa, dengan jumlah sampel sebanyak 60 orang siswa yang dipilih dengan teknik cluster sampling.

Variabel penelitian yang akan diukur dalam penelitian ini ada dua yaitu penggunaan fasilitas belajar (X) dan motivasi belajar (Y). Pengumpulan data kedua variabel menggunakan angket yang sebelumnya telah dilakukan uji validitas dan reliabilitasnya baik oleh ahli maupun uji empiris.

Analisis data dalam penelitian ini menggunakan analisis statistik deskriptif, uji prasyarat analisi, dan uji hipotesis dengan menggunakan uji koefisien korelasi kedua variabel.

\section{HASIL DAN PEMBAHASAN}

Berdasarkan hasil perhitungan data penelitian, dapat diketahui bahwa skor tertinggi $(\mathrm{Xt})$ vpenggunaan fasilitas belajar sebesar 34 dan skor terendah (Xr) sebesar 14 dengan skor rata-rata (X) sebesar 26,9 dengan median (Me) sebesar 24,51, Modus sebesar 24,84 dan standar deviasi 4,5536.

Skor rata-rata yang dperoleh siswa $(\mathrm{X}=26,9)$ dibandingkan dengan skor median teoritis $(\mathrm{Me}=25)$ seperti yang ditunjukkan pada gambar 5.1 berikut:

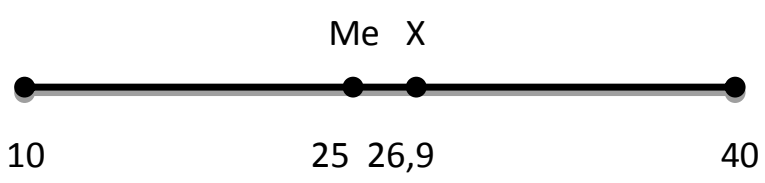

Gambar 1.Perbandingan Skor Rata-Rata Dengan Median Penggunaan Fasilitas Belajar

Gambar 1 menunjukkan bahwa skor rata-rata yang dperoleh siswa $(X=26,9)$ lebih tinggi dari skor median teoritis $(\mathrm{Me}=$ 25). Hasil tersebut dapat ditafsirkan bahwa penggunaan fasilitas belajar siswa SMAN 1 


\section{Chemistry Education Practice, 4 (3), 2021 - 284}

Pratiwi, Wildan, Loka, Muntari

Pringgrata relative sudah baik.Hal tersebut dapat dipahami, saat ini sebagian besar siswa sudah memiliki fasilitas belajar daring, seperti handphone dan laptop dan didukung oleh adanya kebijakan pulsa belajar dari Kemendikbud Ristek. Hal ini juga didukung pula oleh pernyataan wakil kepala sekolah dan didung oleh pernyataan guru kimia, yang mengatakan bahwa..

"Siswa pada umumnya sudah mahir menggunakan peralatan untuk belajar daring, karena rata-rata mereka sudah punya Android, dan Laptop, bahkan banyak guru yang belajar dari siswa tentang cara mencari sesuatu informasi dari dari google maupun dari sumber informasi lainnya".

Fakta tersebut didukung pula oleh hasil penelitian dari Noviansyah (2021), yang menyatakan bahwa siswa dalam mengikuti pembelajaran daring susah siap baik dari sisi mental, fisik maupun teknologi. Pembelajaran daring di masa pandemi adalah pembelajaran yang memanfaatkan teknologi informasi dan komunikasi di dalam menyampaikan materi pembelajaran sehingga siswa yang notabena generasi abad 21 sudah terbiasa dalam memanfaatkan platform teknologi dalam kehidupan sehari-hari. Sehingga, siswa lebih mudah beradaptasi di dalam penggunaan teknologi pada proses pembelajaran daring.

Berdasarkan hasil perhitungan dengan statistik deskriptif, diketahui bahwa skor motivasi belajar siswa tertinggi $(\mathrm{Xt})$ sebesar 48 dan skor terendah sebesar $21(\mathrm{Xr})$, skor ratarata $(\mathrm{X})$ sebesar 33,1 dengan median $(\mathrm{Me})$ sebesar 32,06, modus sebesar 30,66 dan standar deviasi 6,154.

Skor rata-rata yang dperoleh siswa $(\mathrm{X}=$ 30,66) dibandingkan skor median teoritis (Me $=37,5)$ seperti yang ditunjukkan pada gambar 5.2 berikut:

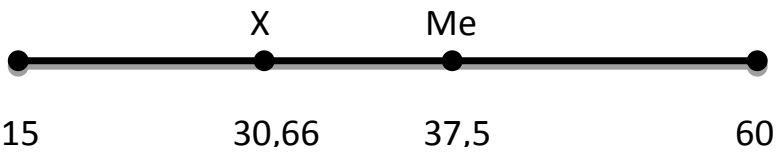

Gambar 2. Perbandingan Skor Rata-Rata dengan Median Motivsi Belajar

Berdasarkan gambar diatas menunjukan bahwa skor rata-rata yang dperoleh siswa $(\mathrm{X}=$
30,66) lebih kecil dibandingkan skor median teoritis $(\mathrm{Me}=37,5)$. Hasil tersebut dapat ditafsirkan bahwa motivasi belajar siswa SMAN 1 Pringgrata relative rendah. Seperti yang diketahui, pada dasarnya motivasi belajar merupakan hal yng sangat penting dalam proses pembelajaran.

Peran motivasi dalam belajar dapat menumbuhkan rasa senang, semangat untuk belajar, dan bergairah. Apabila motivasi belajar siswa masih rendah saat pembelajaran online, hal ini dapat disebabkan ketika proses pembelajaran daring ini berlangsung siswa merasa bosan dengan pembelajaran tersebut, karena siswa menjadi kurang aktif dalam penyampaian pendapat dan pemikirannya, sehingga menyebabkan proses belajar yang membosankan. Adanya pembelajaran yang membosankan tersebut maka pembelajaran tidak berlangsung secara efektif dan efisien sehingga dapat menyebabkan kurangnya motivasi belajar pada siswa. Oleh karena itu diperlukan adanya pendorong yang dapat menggerakkan siswa agar lebih semangat dalam belajar yang nantinya dapat menyebabkan motivasi belajar siswa tinggi. Berdasarkan hal tersebut, menjadi tantangan bagi guru untuk mengembangkan pendekatan pembelajaran daring yang dapat meningkatkan motivasi belajar siswa.

Menurut Suhaemi (2020), dalam meningkatkan motivasi belajar siswa, terdapat beberapa peran yang harus dimiliki oleh guru yaitu, menciptakan metode pembelajaran yang bervariasi dan inovatif, meningkatkan antusias dan semangat dalam mengajar, dan memberikan penghrgaan.

Sebelum dilanjutkan dengan uji hipotesis penelitian, terlebih dahulu dilakukan uji prasyarat analisis, yaitu uji normalitas, uji homogenitas varian, dan uji linieritas.

Diperoleh $\quad \boldsymbol{X}^{\mathbf{2}}$ hitungpenggunaan fasilitas belajar sebesar 7,59294 dan $\boldsymbol{X}^{\mathbf{2}}$ hitungmotivasi belajar siswa sebesar 7,81802. Sedangkan nilai $\boldsymbol{X}^{\mathbf{2}}$ tabelpada taraf signifikan $5 \%$ sebesar 12,592.Dari perhitungan normalitas tersebut, nilai $\boldsymbol{X}^{\mathbf{2}}$ hitungdata penggunaan fasilitas belajar dan motivasi belajar siswa lebih kecil dari 


\section{Chemistry Education Practice, 4 (3), 2021 - 285}

Pratiwi, Wildan, Loka, Muntari

$\boldsymbol{X}^{\mathbf{2}}$ tabelmaka data dikatakan penggunaan fasilitas belajar dan motivasi belajar siswa terdistribusi normal.

Uji homogenitas data kedua variabel menggunakan uji F. Dari hasil perhitungan diperolehF $F_{\text {hitung }}=1,27<\mathrm{F}_{\text {tabel }}=1,54$. Dengan demikian data kedua variabel bersifat homogen.

Hubungan antara penggunaan Fasilitas Belajar (X) dengan Motivasi Belajar Siswa ditunjukkan oleh persamaan regresi $\hat{Y}=15,162$ $+0,671 \mathrm{X}$ dan hasil pengujiian regresi $\hat{\mathrm{Y}}=$ $15,162+0,671 X$ signifikan dan linear. Grafik persamaan regresi tersebut dapat digambarkan sebagai berikut.

Koefisien korelasi $\left(\mathrm{r}_{\mathrm{xy}}\right)$ kedua variabel yang dihitung menggunakan rumus Product Moment Pearson sebesar 0,529 dengan $\mathrm{r}_{\text {tabel }}$ sebesar 0,254 dengan $\mathrm{n}=60$ dan taraf signifikan $5 \%$ sehingga $r_{\text {hitung }}>r_{\text {tabel. }}$ Dengan demikian terdapat hubungan yang positif dan signifikan antara penggunaan fasilitas belajar dengan motivasi belajar kimia pada era wabah covid-19 pada siswa kelas XI IPA SMAN 1 Pringgarata. Artinya, semakin baik penggunaan fasilitas belajar, maka akan semakin baik juga motivasi belajar siswa. Hal ini dapat disebabkan karena ketika fasilitas yang dimiliki digunakan dengan sebaik mungkin terutama untuk belajar, maka akan meningkatkan motivasi belajar siswa. Sesuai dengan pendapat Arsyad (2014: 25), yang menyatakan bahwa, pemanfaatan sarana belajar apabila dimanfaatkan dengan baik dapat memberikan beberapa manfaat. Salah satu manfaat tersebut ialah untuk menggairahkan dan meningkatkan perhatian siswa sehingga dapat menimbulkan motivasi belajar siswa.

Koefisien determinasi penggunaan fasilitas belajar terhadap motivasi belajar pada penelitian ini sebesar 28,04. Dengan demikian penggunaan fasilitas belajar memberikan sumbangan atau kontribusi terhadap motivasi belajar siswa sebesar $28,04 \%$.

Berdasarkan hasil di atas, maka implikasinya adalah guru di dalam melaksanakan pembelajaran dengan system daring dituntut untuk mengembangkan pembelajaran yang menantang siswa untuk belajar secara mandiri, seperti mengembangkan pembelajaran digital dan pembelajaran inovatif. Sehingga, tugas guru kedepan adalah mencari gagasan-gagasan inovatif dan kreatif untuk mempertinggi mutu pembelajaran.

Salah satu kopetensi yang harus dimiliki guru adalah mengintegrasikan teknologi dalam proses pembelajaran. Contohnya menerapkan model pembelajaran inovatif berbasis TIK dengan pendekatan pembelajaran berbasis masalah, pendekatan discovery learning dengan memanfaatkan multimedia interaktif untuk meningkatkan tantangan kepada siswa dalam memanfaatkan fasilitas belajar daring, sehingga dapat meningkatkan motivasi belajar siswa secara daring.

\section{SIMPULAN}

Berdasarkan hasil penelitian dan pembahasan dapat disimpulkan bahwa terdapat hubungan yang positif dan signifikan antara penggunaan fasilitas belajar siswa dan motivasi belajar kimia pada era wabah covid-19 pada siswa kelas XI IPA SMAN 1 Pringgarata tahun 2021.Kontribusi penggunaan fasilitas belajar terhadap motivasi sebesar $28,04 \%$.

Salah satu implikasi yang terpenting dalam penelitian ini adalah untuk meningkatkan motivasi belajar siswa dapat dilakukan dengan meningkatkan kualitas penggunaan fasilitas belajar dengan cara, guru harus mampu mengembangkan pembelajaran dengan pendekatan yang inovatif, guru harus mengurangi pemberian informasi tentang materi yang bersifat hafalan, guru harus mampu memberikan materi dan tugas yang menantang kepada siswa.

\section{DAFTAR PUSTAKA}

Adiputra, S., dan Mujiyati., (2017). Motivasi dan Prestasi Belajar Siswa di Indonesia. Jurnal Kajian MetaAnalisis, Vol. 6, No. 4 hal: 150-157.

Aji, R. H. S., (2020). Dampak Covid-19 pada Pendidikan di Indonesia: Sekolah, Keterampilan, dan Proses Pembelajaran. Jurnal Sosial \& Budaya Syar-I, Vol. 7, No. 5 hal: 395-402. 
Ariani, S., Siahaan, J., \& Junaidi, E. (2013). Pengaruh Penggunaan Media Kartu Dengan Metode Chemo-edutainment Terhadap Hasil Belajar Kimia Pada Materi Pokok Hidrokarbon Kelas X SMA Negeri 1 Kuripan Tahun Ajaran 2012/2013. Jurnal Pijar Mipa, 8(1).

Arifa, N. F., (2020). Tantangan Pelaksanaan Kebijakan Belajar dari Rumah dalam Masa Darurat Covid-19. Info Singkat, Vol. 12, No. 7 hal: 13-18.

Arsyad, A., (2014). Media Pembelajaran. Jakarta: Rajawali Pers.

Cahyani, A., Listiana, L. D., dan Sari, P. D. L., (2020). Motivasi Belajar Siswa SMA pada Pembelajaran Daring di Masa Pandemi Covid-19. Jurnal Pendidikan Islam, Vol. 3, No. 1 hal: 123-140.

Djuarsa, R. N., Chrismastianto, A. W., dan Hidayat, D., (2017). Hubungan Motivasi Belajar Siswa dengan Persepsi Siswa dalam Berprestasi. A Journal of Language, Literature, Culture, and Education Polyglot, Vol. 13, No. 1 hal: 21-34.

Firman., dan Rahman, S. R., (2020). Pembelajaran Online di Tengah Pandemi Covid-19. Indonesian Journal of Educational Science (IJES), Vol. 2, No. 2 hal: 81-89.

Kusuma, D. A. (2020). Dampak penerapan pembelajaran daring terhadap kemandirian belajar (self-regulated learning) mahasiswa pada mata kuliah geometri selama pembelajaran jarak jauh di masa pandemi covid-19. Teorema: Teori dan Riset Matematika, 5(2), 169-175.
Muhammad, H., Agus, E., dan Basori., (2019). Pengaruh Fasilitas Belajar Berbasis Teknologi Terhadap Prestasi Belajar Siswa. Jurnal Ilmiah Pendidikan Teknik Kejuruan, Vol. 12, No. 1 hal: 56-64.

Noviansyah, W., (2021). Analisis Kesiapan dan Hambatan Siswa SMK dalam Menghadapi Pembelajaran Daring di Masa Pandemi. Jurnal Studi Guru dan Pembelajaran, Vol. 4, No.1 hal: 82-88.

Rachmawati, Y., dan Muh. M., (2020). Studi Eksplorasi Pembelajaran Pendidikan IPA saat Masa Pandemi COVID-19 di UIN Sunan Ampel. Indonesian Journal of Scienc Learning, Vol. 1, No. 1 hal: 32-36.

Roskiana., Savalas, L. R. T., dan Sukib., (2020). Hubungan Pemanfaatan Fasilitas Belajar dan Kemandirian Belajar dengan Hasil Belajar Kimia Siswa Kelas XI IPA SMA Negeri 3 Mataram Tahun 2018/2019. Chemistry Education Practice, Vol. 3, No. 1 hal: 29-33.

Suhaemi, A. N., Laurenza, D., Pandu, F. B., dan Abhista, D. P. (2020). Peran Guru dalam Meningkatkan Motivasi Belajar Daring di Era Pandemi Covid-19, hal: 195-199.

Zahro, S. F., dan Ismono. (2021). Analisis Kemampuan Multirepresentasi Siswa Pada Materi Kesetimbangan Kimia di Masa Pandemi Covid-19. Chemistry Education Practice, Vol. 4, No. 1 hal: 30-39. 